\title{
Anti-tumor role of Bacillus subtilis fmbJ-derived fengycin on human colon cancer HT29 cell line
}

\author{
W. CHENG ${ }^{1}$, Y. Q. FENG ${ }^{2}$, J. REN ${ }^{3}$, D. JING ${ }^{4}$, C. WANG ${ }^{5, *}$
}

${ }^{1}$ Department of general surgery, Yantai mountain hospital, Yantai 264000, China; ${ }^{2}$ Department of Laboratory, the second people's hospital of liaocheng, linqing, 252600, China; ${ }^{3}$ Department of gastroenterology, Yantai mountain hospital, Yantai 264000, China; ${ }^{4}$ Department of Cadres Health Care, Third Hospital of Shijiazhuang, Shijiazhuang, Hebei 050011, China; ${ }^{5}$ Department of oncology, Central hospital of Wuhan, Tongji Medical College, Huazhong University of Science and Technology, Wuhan, China

${ }^{*}$ Correspondence: chunwang616@126.com

Received May 18, 2015 / Accepted September 21, 2015

To explore the potential clinical anti-tumor roles of Bacillus subtilis fmbJ-derived fengycin on cell growth and apoptosis in colon cancer HT29 cell line.

Fengycin was extracted from Bacillus subtilis fmbJ and detected using HPLC. The effects of different concentration of fengycin on colon cell HT29 cell activity at different time points were analyzed using MTT assay. ROS level in colon HT29 cells affected by fengycin was detected using DCFH-DA method, followed by measuring the effects of fengycin on HT29 cell apoptosis and cell cycle by flow cytometry. The effects of fengycin on Bax/Bcl-2, CDK4/cyclin D1, Caspase-6 and Caspase-3 expressions in HT29 cells were analyzed using western blot. Also, mRNA levels of Bax/Bcl-2 and CDK4/cyclin D1 in HT29 cells affected by fengycin were analyzed using qRT-PCR.

Compared with controlss, $20 \mu \mathrm{g} / \mathrm{mL}$ of fengycin performed an inhibit role on HT29 cell growth of at 3 day $(\mathrm{P}<0.05)$, and high dose of fengycin showed more excellent effect on inhibiting HT29 cell growth with time increasing. Besides, fengycin could induce HT29 cell apoptosis and affect the cell cycle arrest at G1. ROS level in HT29 cells treated by fengycin was significantly increased compared with that in control group $(\mathrm{P}<0.05)$. Western blot analysis showed that after being treated with fengycin, Bax, Caspase-3, and Caspase-6 expressions were increased, however, Bcl-2, and CDK4/cyclin D1 expressions were decreased $(\mathrm{P}<0.05)$.

Our study suggested that fengycin may play certain inhibit roles in the development and progression of colon cancer through involving in the cell apoptosis and cell cycle processes by targeting the Bax/Bcl-2 pathway.

Key words: colon cancer cell line HT29, fengycin, cell apoptosis, reactive oxygen species, Bax/Bcl-2 pathway

Colon cancer is the second most common digestive tract malignancy that arises from the junction position from dentate line to sigmoid colon and rectal [1]. The morbidity and mortality of colon cancer are high, and statistics has shown that approximate 96,830 new cases are diagnosed as colon cancer, in which 50,310 are deaths [2]. Studies refer that the main treatment methods for colon cancer are drug therapy, chemotherapy, and surgery, however, the clinical results for colon cure are not satisfactory due to its hard detection and easy metastasis [3, 4]. Therefore, it will be of great significance to investigate several new and effective treatment drugs for colon treatment in clinical.

Recently, the clinical relevance and therapeutic implications of antibacterial peptides, which was derived from bacteria, fungi, and plants, have becoming the hotpot in many diseases
[5]. For example, the high expression of plectasin-derived peptide NZ2114 performs an excellent inhibit role against the pyogenic infection bacteria Staphylococcus aureus [6]. The Bacillus subtilis-derived lipid peptides, are some biosurfactant that composed by hydrophilic peptide chain of fat and hydrocarbon chain of oil, play crucial roles in anti-fungi, anti-bacteria, and anti-tumor [7]. Fengycin is a member of the three kinds of lipid peptides that derived from Bacillus subtilis. Increasing evidence has referred that fengycin functions as an important inhibitor in many diseases, such as cancers [8]. Fengycin inhibits the lung cancer cell growth in $95 \mathrm{D}$ cells by enhancing reactive oxygen species (ROS) expression [9]. Besides, previous study refers that Bacillus subtilis-derived fmbJ performed some anti-virus and anti-tumor roles in vitro [10]. The marine bacterium-derived fengycin has cytotoxic activ- 
ity against colon cancer cell line [11], and fengycin performs inhibit roles on cell viability and proliferation of breast cancer [12]. Although several researches have devoted to the application of antibacterial peptide fengycin on a variety of cancers in clinical, the anti-tumor role of fengycin on colon cancer still remains largely unknown.

In this present study, we investigated the biological roles of Bacillus subtilis fmbJ -derived antibacterial peptide fengycin on colon cancer cell growth using colon HT29 cell line. Comprehensive biological experimental methods were used to analyze the effects of fengycin on ROS level, cell cycle, apoptosis, and apoptosis-related protein levels in colon cancer HT29 cell line. This study aimed to explore the potential role of fengycin on tumor development of colon cancer and their potential mechanisms. Our experimental research may provide basis for clinical use of antibacterial peptide fengycin on colon tumor treatment.

\section{Materials and methods}

Materials and cell culture. Antimicrobial peptide of fengycin that produced by B. subtilis strain fmbJ (CGMCC No.0943) (purchased from Beihai qunlin shengwu LOTD, Guangxi) in an optimized culture medium was extracted using the High Performance Liquid Chromatography (HPLC) analysis, followed by the identification of isolated fengycin by electrospray ionization mass spectrometry (ESI-MS) as previously described [13]. The human colon cancer cell line HT29, breast cancer cell line MCF-7, and normal human colon epithelial cell line PriCells were purchased from Y-Y Chemical reagents (Shanghai, China). Colon HT29 cells and breast MCF-7 cells were cultivated in RPMI 1640 (Gibco, Grand island, NY) supplemented with $10 \%$ fetal bovine srum (FBS) and $100 \mu \mathrm{g} / \mathrm{mL}$ penicillin, while colon epithelial cell line PriCells were growth in DMEM (Gibco, Grand island, NY) containing 10\% FBS and $100 \mu \mathrm{g} / \mathrm{mL}$ penicillin. Total cells were cultivated in culture flaskes at $37^{\circ} \mathrm{C}$ in a humidified atmosphere with $5 \% \mathrm{CO}_{2}$.

MTT assay. Cell survival rate and sensitivity of the total cultivated tumor cells were detected using the MTT (3-(4,5dimethyl-2-thiazolyl)-2,5-diphenyl tetrazolium bromide) assay as previously described [14]. Briefly, tumor cells were transferred into 96-well plates containing RPMI 1640 with $10 \%$ FBS. After being cultivated for several hours, cells at logarithmic phase were digested with $0.25 \%$ trypsin to adjust the cell density at $1 \times 10^{4}$ cells/well. Then, different concentration of fengycin (from 0 to $200 \mu \mathrm{g} / \mathrm{mL}$ ) were added into cells for another $72 \mathrm{~h}$ of incubation. Each assay was performed for 6 repeats and repeated for 3 times independently. Consequently, MTT ( $5 \mathrm{mg} / \mathrm{mL}$ ) (Sigma, USA) was added into the 96 -well plates to mix with cells at $37^{\circ} \mathrm{C}$ for 4 h. Followed by removing the supernatant and adding into 150 $\mu \mathrm{L}$ dimethyl sulfoxide to dissolve the formazan. The absorbance of cells in each plate was detected using the microplate reader (THERMOMultiskan M3, USA) at $570 \mathrm{~nm}$.

Intracellular ROS level measurement. DCFH-DA (2', 7'dichlorohydrofluorescein) is an unlabeled oxidation sensitive fluorescence probe that can be oxidized into DCF by intracellular ROS, so as to be the marker for detecting the intracellular ROS level [15]. In this study, DCFH-DA (Sigma) was used to determine the production of ROS level in HT29 cells by flow cytometry. Briefly, HT29 cells treated with $200 \mu \mathrm{g} / \mathrm{mL}$ of fengycin at different time points $(0,6,12$, and $24 \mathrm{~h})$ were mixed with $10 \mu \mathrm{mol} / \mathrm{mL}$ of DCFH-DA at $37^{\circ} \mathrm{C}$ for $30 \mathrm{~min}$ in dark place. Consequently, cells were washed with PBS buffer for 3 times, and then the product of DCF fluorescence was detected using the FACScan flow cytometry (BD, California, USA) at an wavelength of $495 \mathrm{~nm}$.

Cell apoptosis. Effect of different concentration of fengycin on tumor cell apoptosis was quantified with a flow cytometry using the annexin-V-FITC Apoptosis Detectcion Kit (CLONTECH Laboratories, Palo Alto, CA) according to the manufacturer's protocol [16]. Briefly, cells were treated with fengycin with three concentrations $(100,200$, and $400 \mu \mathrm{g} /$ $\mathrm{mL}$ ) for $24 \mathrm{~h}$ and $48 \mathrm{~h}$ respectively. Then the total cells were harvested and was washed with cold PBS buffer (PH 7.4), and then cells were resuspended in $500 \mu \mathrm{L}$ of annexin- $\mathrm{V}$ binding buffer. After that, $5 \mu \mathrm{L}$ of annexin-V-FITC and $5 \mu \mathrm{L}$ of propidium iodide (PI) were mixed with the cells for $10 \mathrm{~min}$ at room temperature. Then mixtures were analyzed using the FACScan flow cytometry.

Cell cycle. The effect of fengycin on colon HT29 cell cycle was determined uisng flow cytometry to analyze the total amount of DNA [17]. In a word, cells (at a density of $4 \times 10^{5}$ cells/ well) were transferred into 6-well plates. Then fengycin with various concentrations of 100,200 and $400 \mu \mathrm{g} / \mathrm{mL}$ were added into the cells for $6 \mathrm{~h}, 12 \mathrm{~h}$, and $24 \mathrm{~h}$ respectively. The cultivated cells were centrifuged at 12,000 for $5 \mathrm{~min}$ and were washed with PBS buffer for 3 times, followed by resuspended with cold PBS and $20 \mathrm{mg} / \mathrm{mL}$ of RnaseA (Sigma) application for $30 \mathrm{~min}$ at $37^{\circ} \mathrm{C}$. Then $50 \mathrm{mg} / \mathrm{mL}$ of PI mixed in PBS buffer was added into the cells for $30 \mathrm{~min}$ at room temperature in dark place. Finally, cell cycle phase was detected using flow cytometry.

Western blotting analysis. Colon cancer HT29 cells treated with $200 \mu \mathrm{g} / \mathrm{mL}$ fengycin at different time points $(0 \mathrm{~h}, 6 \mathrm{~h}, 12$ $\mathrm{h}$ and $24 \mathrm{~h}$ ) were centrifuged at 12,000 rpm/min for $5 \mathrm{~min}$ at $4^{\circ} \mathrm{C}$ [15]. The supernatant was collected to determine the concentration of protein using the bicinchoninic acid (BCA) protein assay kit (Pierce, Rochford, IL). Briefly, a total of 20 $\mu \mathrm{g}$ protein per cell lysates was subjected to a $10 \%$ SDS-PAGE (sodium dodecylsulfate-polyacrylamide gel electrophoresis) and then transferred onto a Polyvinylidencefluoride (PVDF) membrane (Mippore). The membranes were blocked in TBST (Tris-buffered Saline Tween) with 5\% non-fat milk for $1 \mathrm{~h}$. Subsequently, the membranes were incubated with rabbit antihuman monoclonal antibodies (1:100 dilution; Cycline D1, CDK4, Bcl-2, Bax, CytC, Caspase-3 and Caspase-6, Bioworld, St Louis Park, Minnesota, USA; $\beta$-actin (mAbcAM 8226), Cambridge, UK) overnight at $4^{\circ} \mathrm{C}$, followed by incubation with horseradish peroxidase labeled goat anti-rat secondary antibody (1:100 dilution) at room temperature for $1 \mathrm{~h}$. The membranes were washed using the $1 \times$ TBST buffer for $10 \mathrm{~min}$ with 3 times. The signals were detected after incubation with a chromog- 
enic substrate using the enhanced chemiluminescence (ECL) method. In addition, $\beta$-actin served as the internal control.

Quantitative RT-PCR analysis. Colon HT29 cells treated with $200 \mu \mathrm{g} / \mathrm{mL}$ of fengycin at different time points $(0 \mathrm{~h}$, $6 \mathrm{~h}, 12 \mathrm{~h}$, and $24 \mathrm{~h}$ ) were centrifuged at 12,000 rpm/min for $5 \mathrm{~min}$ at $4^{\circ} \mathrm{C}$, followed by washed with PBS buffer (PH 7.4) for 3 times. Total RNA from the harvested HT29 cells was extracted using the Trizol reagent [18] (Invitrogen, Carlsbad, CA) and treated with RNase-free DNase I (Promega Biotech). The concentration and purity for extracted RNA were detected using SMA4000 UV-VIS (Merinton, Shanghai, China). The purified RNA $(0.5 \mu \mathrm{g} / \mu \mathrm{L})$ mixed with nuclease-free $\mathrm{ddH}_{2} \mathrm{O}$ was used for cDNA synthesis using the PrimerScript $1^{\text {st }}$ Strand cDNA Synthesis Kit (Takara, China). Primers for the targets amplification were shown in Table 1. Then RT-PCR was carried out in an Eppendorf Mastercycler (Brinkman Instruments, Westbury, NY) using the SYBR ExScript RT-qPCR Kit (Takara, China). The reaction system of $20 \mu \mathrm{L}$ volume containing $1 \mu \mathrm{L}$ cDNA from the above PCR, $10 \mu \mathrm{L}$ SYBR Premix EX Taq, $1 \mu \mathrm{L}$ each of the primers $(10 \mu \mathrm{M})$, and $7 \mu \mathrm{L} \mathrm{ddH}_{2} \mathrm{O}$. Melting curve analysis of amplification products was performed at the end of each PCR to confirm that only one product was amplified and detected. GAPDH (glyceraldehyde-3-phosphate dehydrogenase) was used as the internal control.

Statistical analysis. All the experiments were conducted independently 3 times. Data are presented as the mean \pm SEM

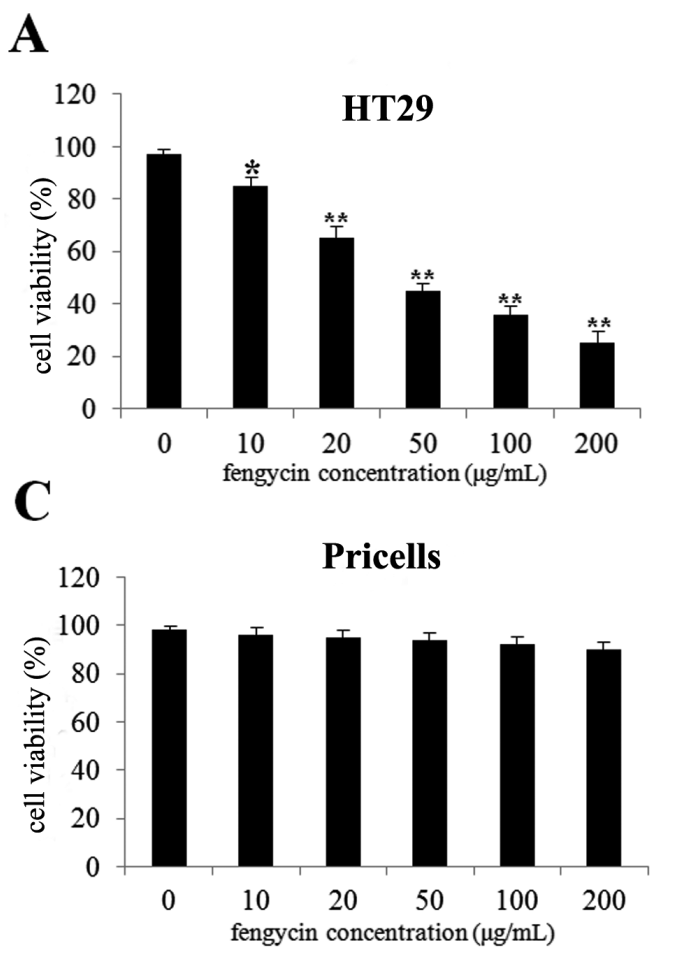

Table 1. Primers used for targets amplification in this study

\begin{tabular}{lll}
\hline Name & primer & Sequence (5'-3') \\
\hline GAPDH & Sense & TATGATGATATCAAGAGGGTAGT \\
& Antisense & TGTATCCAAACTCATTGTCATAC \\
Bax & Sense & ATGGACGGGTCCGGGGAG \\
& Antisense & TCAGAAAACATGTCAGCTGCC \\
Bcl-2 & Sense & TTGTGGCCTTCTTTGAGTTCGGTG \\
& Antisense & GGTGCCGGTTCAGGTACTCAGTCA \\
CDK4 & Sense & GAGGCGACTGGAGGCTTTT \\
& Antisense & TCCTCCTCCTCCTCTTCCTCCTCC \\
Cyclin D1 & Sense & AGTTCATTTCCAATCCGCCCTCC \\
& Antisense & TCCTCCTCCTCCTCTTCCTCCTCC \\
\hline
\end{tabular}

(standard error of mean). Statistically analyses were performed using SPSS 13.0 (Chicago, IL, USA). Statistical comparisons between two groups were conducted using one-way ANOVA (analysis of variance). Student post hoc multiple test was used to calculate the statistical significance among groups. $\mathrm{P}<0.05$ was considered to indicate a significant difference.

\section{Results}

Effect of fengycin on colon cell proliferation. MTT assay was used to assess the effects of fengycin on colon HT29 cell

\section{B}
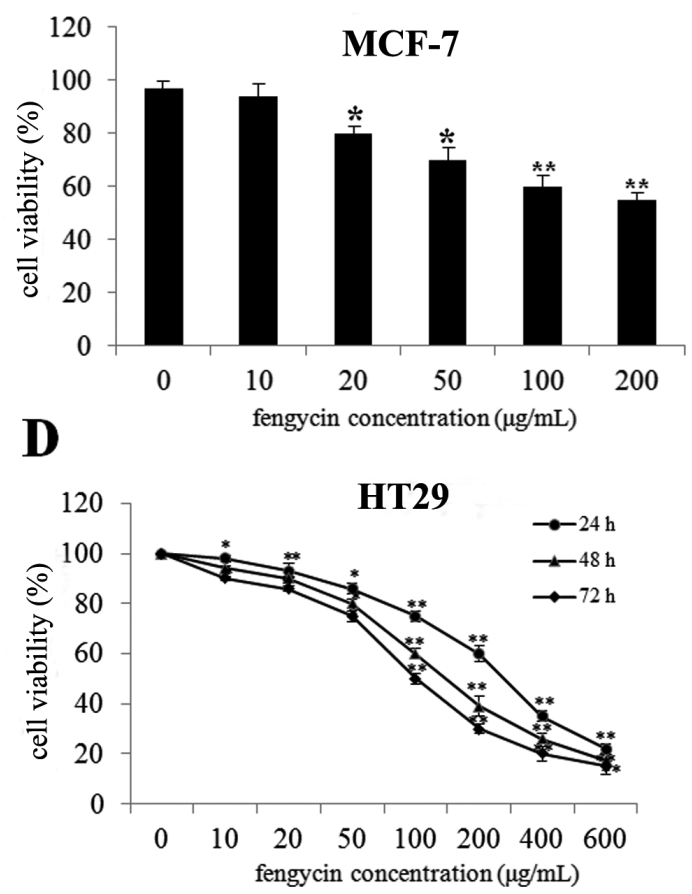

Figure 1. Effects of fengycin on tumor cell viability. A-C: effects of fengycin on tumor cell viability, including colon HT29, breast cancer MCF-7 and normal colon epithelial Pricells. The three kinds of cells were treated with different concentration of fengycin for $72 \mathrm{~h}$. $\mathrm{D}$ : effect of different concentration of fengycin (from 0 to $600 \mu \mathrm{g} / \mathrm{mL}$ ) on colon HT29 cells growth at different time points. The cell viability in controls was considered as $100 \%$ percent. ${ }^{*}$ : $\mathrm{P}<0.05,{ }^{* *}: \mathrm{P}<0.01$ compared to control (cells treated with fengycin at $\mathbf{0 ~ h}$ ). 

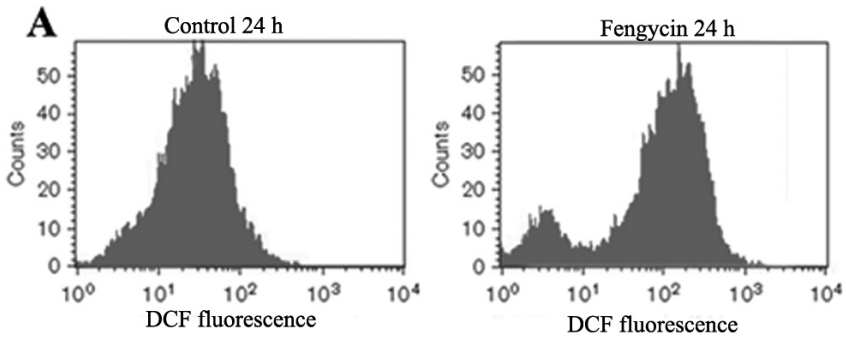

B

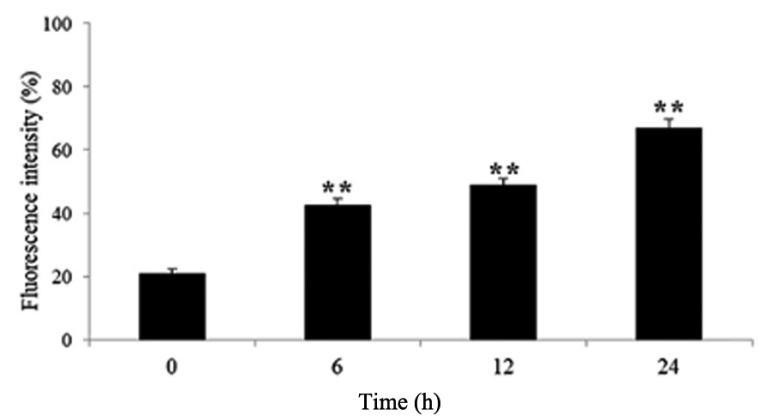

Figure 2. Influence of fengycin on reactive oxygen species (ROS) level in HT29 cells. A: DCFH-DA analysis on ROS level in HT29 cells treated with $200 \mu \mathrm{g} / \mathrm{mL}$ fengycin at $24 \mathrm{~h}$; B: flow cytometry analysis of ROS in HT29 cells treated with $200 \mu \mathrm{g} / \mathrm{mL}$ fengycin at different time points. ${ }^{* *}$ stands for $\mathrm{P}<0.01$ compared with control group $(0 \mathrm{~h})$.

proliferation (Figure 1). After $72 \mathrm{~h}$ of incubation, fengycin of $10 \mu \mathrm{g} / \mathrm{mL}$ performed statistical difference on HT29 cell proliferation compared with the control $(0 \mu \mathrm{g} / \mathrm{mL} ; \mathrm{P}<0.05)$, and high dose of fengycin showed an excellent inhibit role on HT29 cell proliferation (Figure 1A). The results also showed that there was no significant difference of fengycin with various concentrations on normal colon epithelial Precells cell proliferation (Figure 1C). Besides, fengycin of $20 \mu \mathrm{g} / \mathrm{mL}$ showed statistical difference on MCF-7 cell proliferation compared to control group $(0 \mu \mathrm{g} / \mathrm{mL} ; \mathrm{P}<0.05$, Figure $1 \mathrm{~B})$, suggesting that colon HT29 cells were more sensitive to fengycin compared to the breast cancer MCF-7 cell. Moreover, our results showed that colon HT29 cell proliferation was significantly decreased when in a time-dependent and dose-dependent way (Figure 1D).

ROS level measurement. DCFH-DA method was used to measure the ROS level in intra-HT29 cells that treated with fengycin (Figure 2). The results showed that a significant production of ROS in HT29 cells treated with $200 \mu \mathrm{g} / \mathrm{mL}$ of fengycin was detected at $24 \mathrm{~h}$ (Figure 2A). Also, compared with the control group $(0 \mathrm{~h})$, the mean DCF fluorescence in HT29 cells treated with fengycin at $6 \mathrm{~h}$ was statistically increased from $21.2 \%$ to $42.6 \%(\mathrm{P}<0.05)$, and the effect was more apparent when cells were treated with the same fengycin concentration with time increasing $(\mathrm{P}<0.01$, Figure $2 \mathrm{~B})$.

Cell apoptosis. The effects of fengycin on HT29 cell apoptosis were detected using flow cytometry (Figure 3). HT29 cells treated without or with different concentration of fengycin $(100,200$, and $400 \mu \mathrm{g} / \mathrm{mL})$ for 24 and $48 \mathrm{~h}$ respectively. Flow cytometry of annexin- $\mathrm{V}$ analysis showed that percentage of apoptotic cells in control cells was increased from 5.5\% to $43.2 \%$ compared with that in cells treated with $200 \mu \mathrm{g} / \mathrm{mL}$ fengycin at $24 \mathrm{~h}$ (Figure $3 \mathrm{~A}$ ). Also, the number of apoptotic cells in fengycin treated group was increased more significantly compared with control cells at $48 \mathrm{~h}$ ( $24 \mathrm{~h}$; Figure 3B). In addition, in order to identify the morphological changes of apoptotic HT29 cells induced by fengycin, nuclear of cell DNA was detected using DAPI. Colon HT29 cells were treated with 100 and $200 \mu \mathrm{g} / \mathrm{mL}$ fengycin at $24 \mathrm{~h}$ respectively. The results showed that there were more apoptotic cells in HT29 treated with $200 \mu \mathrm{g} / \mathrm{mL}$ fengycin than that in HT29 cells treated with $100 \mu \mathrm{g} / \mathrm{mL}$ fengycin for $24 \mathrm{~h}$ (Figure 3C).

Cell cycle. Flow cytometry was used to investigate the influence of fengycin on HT29 cell cycle (Figure 4). Compared with the control cells, fengycin with $100 \mu \mathrm{g} / \mathrm{mL}$ could induce cell cycle at G0/G1 stage at $6 \mathrm{~h}(\mathrm{P}<0.05)$, and the effect was more significant in cells treated with high dose of fengycin with time increasing $(\mathrm{P}<0.01$, Figure $4 \mathrm{~A})$. Also, when HT29 cells were treated with $200 \mu \mathrm{g} / \mathrm{mL}$ of fengycin, the induced effect on cell cycle was more apparent compared with that in cells treated with $100 \mu \mathrm{g} / \mathrm{mL}$ of fengycin at $12 \mathrm{~h}$ and $24 \mathrm{~h}$ (Figure $4 \mathrm{~B}$ and $4 \mathrm{C}$ ), indicating that fengycin may induce HT29 cell cycle arrest at G0/G1 stage.

Expressions of cell cycle- and cell apoptosis-related proteins. In order to identify the influence of fengycin on HT29 cells at the protein level, western blotting and qRTPCR analysis were used to determine the cell cycle- and cell apoptosis-related proteins (Figure 5). After being treated with $200 \mu \mathrm{g} / \mathrm{mL}$ fengycin, expressions of cyclin D1 and CDK4 were decreased gradually with time increasing. mRNA levels of cyclin D1 and CDK4 in HT29 treated with fengycin at $6 \mathrm{~h}$ were statistically decreased $(\mathrm{P}<0.05)$, and the effect was decreased more apparently with time increasing $(\mathrm{P}<0.01$, Figure $5 \mathrm{~A}$ and Figure 5C). Besides, compared with the control (0 h), Bcl-2 expression and mRNA level were statistically decreased while Bax expression and mRNA level were statistically increased at $6 \mathrm{~h}(\mathrm{P}<0.05)$, and the effect became more significantly with time increasing $(\mathrm{P}<0.01$, Figure $5 \mathrm{~B}$ and $5 \mathrm{D})$. In addition, our results displayed that the application of fengycin induced the release of cytoplasmic $-\mathrm{c}(\mathrm{CytC})$, cleaved caspase- 3 and cleaved caspase-6 in HT29 cells with time increasing (Figure 5E), indicating the correlation between fengycin and HT29 cell apoptosis. However, when HT29 cells treated with fengycin were mixed with $1 \mathrm{mmol} / \mathrm{L} \mathrm{N}$-acetyl cysteine (NAC), which is an inhibitor for ROS [19], the release of cytoplasmic Cyt-c induced by fengycin in mitochondria was inhibited, implying that cell apoptosis induced by fengycin may be inhibited by NAC.

\section{Discussion}

Colon cancer is the second most common digestive tract malignancy, and with high morbidity and mortality $[1,2]$. Clinical relevance and therapeutic implications on antibacte- 


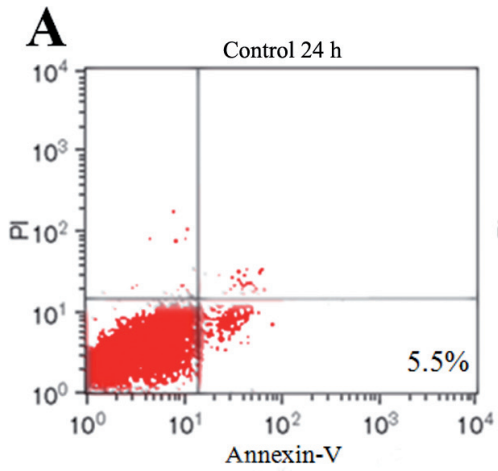

C

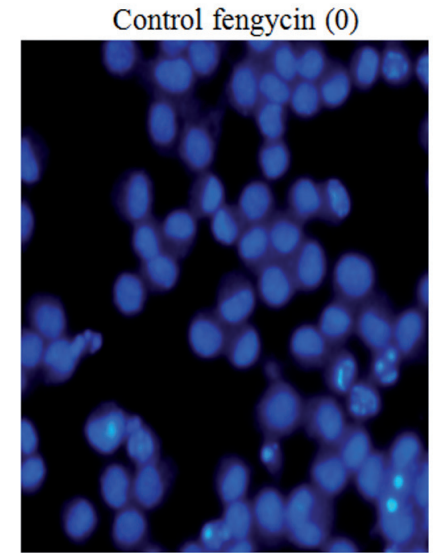

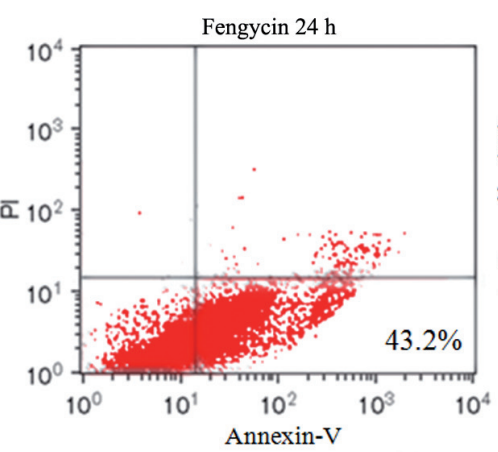
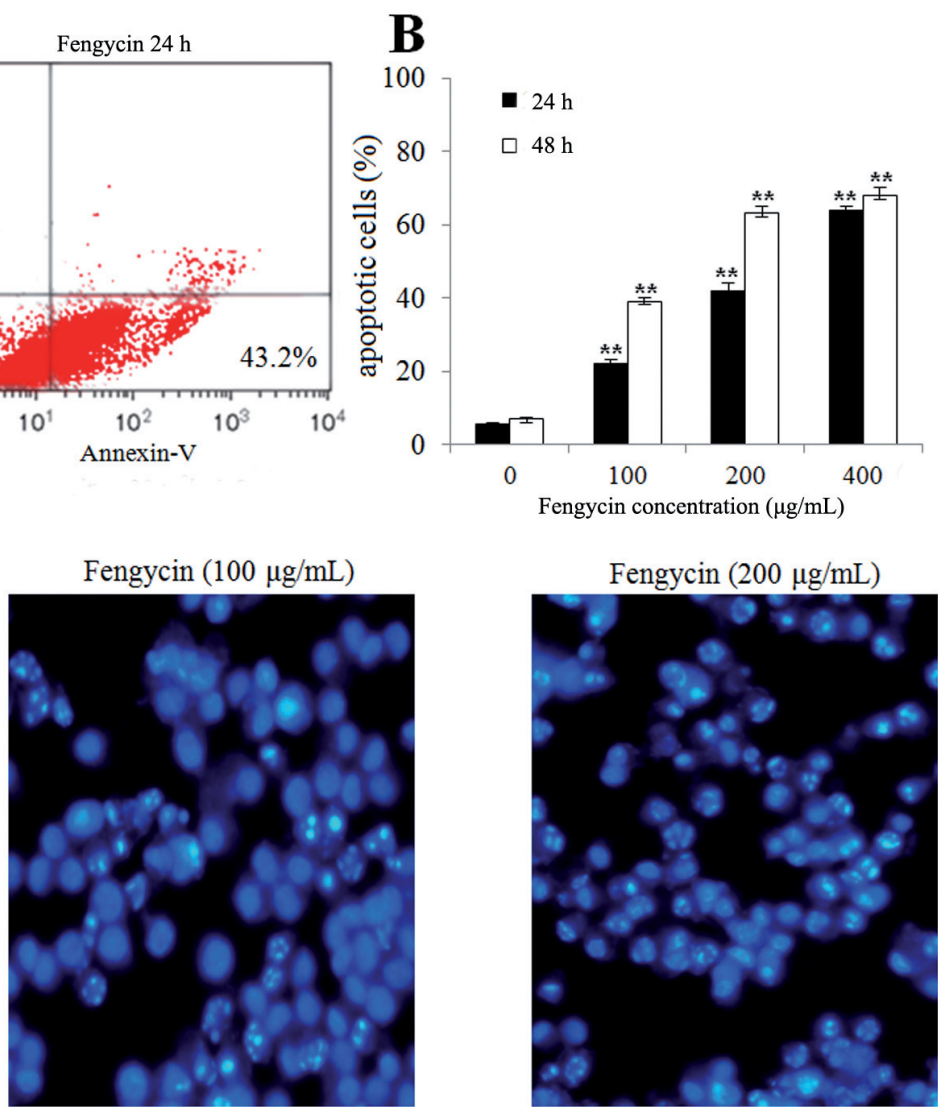

Figure 3. Fengycin induced colon HT29 cell apoptosis. A: Flow cytometry analysis of $200 \mu \mathrm{g} / \mathrm{mL}$ of fengycin on HT29 cell apoptosis at $24 \mathrm{~h}$; B: the effects of different concentration of fengycin on HT29 cell apoptosis at 24 and $48 \mathrm{~h}$; ${ }^{* *}$ stands for $\mathrm{P}<0.01$ compared with the control group $(0 \mu \mathrm{g} / \mathrm{mL})$. C: fluorescence microscope of apoptotic HT29 cells treated with fengycin at $24 \mathrm{~h}(\times 400)$.

rial peptides which is derived from bacteria, fungi, and plants in many diseases have becoming the hotpot [5]. To investigate some new and effective treatment drugs for colon treatment in clinical will be necessary. In this study, we analyzed the potential roles of $B$. subtilis strain fmbJ-derived antimicrobial peptide of fengycin on development and progression of colon cancer using HT29 cells. Our data showed that fengycin could inhibit the development and progression of colon cancer. High dose of fengycin could inhibit colon cell proliferation, induce cell apoptosis, increase intracellular ROS level, and induced cell cycle arrest at G0/G1 stage with time increasing.

Application of antimicrobial peptides in clinical has provided novel significance for disease treatment and bacteria cure in recent years $[20,21]$. Previous paper has proved that
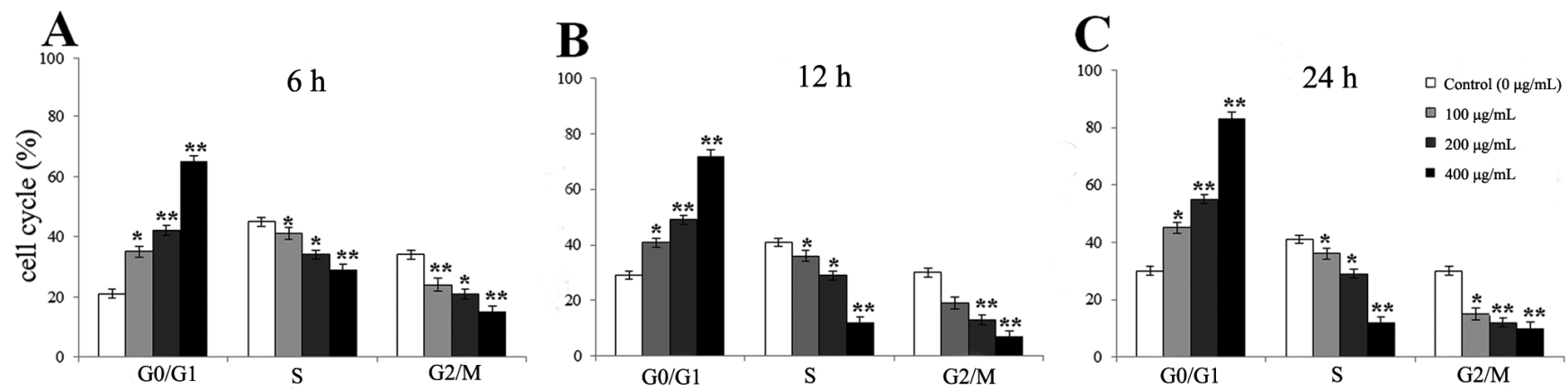

Figure 4. Effect of fengycin on HT29 cell cycle arrest. A-C: effects of different concentration of fengycin on HT29 cell cycle at 6 h, 12 h, and 24 h, respectively. ${ }^{\star}$ stands for $\mathbf{P}<0.05$ and ${ }^{\star *}$ stands for $\mathbf{P}<0.01$ compared with control group $(0 \mu \mathrm{g} / \mathrm{mL})$. 


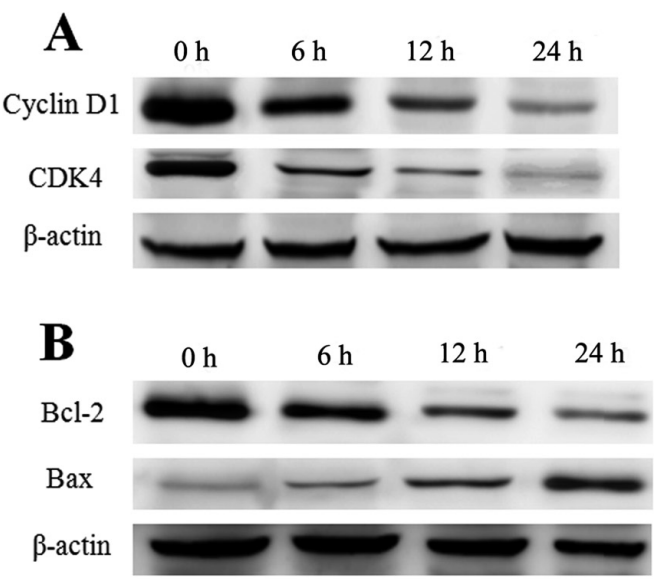

C

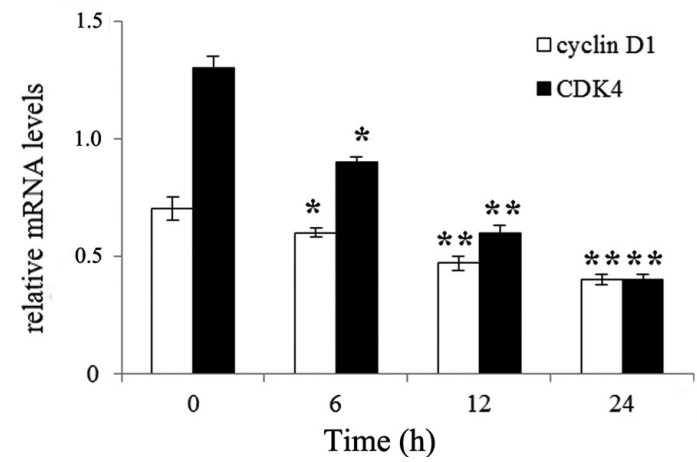

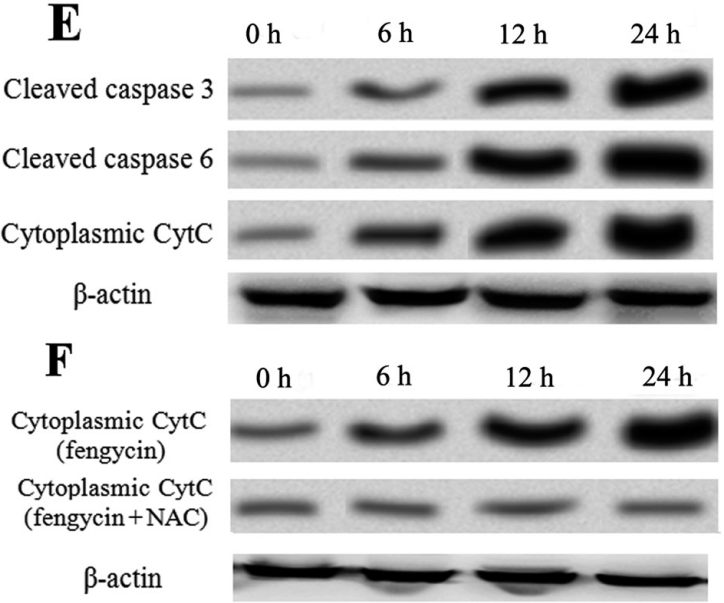

D

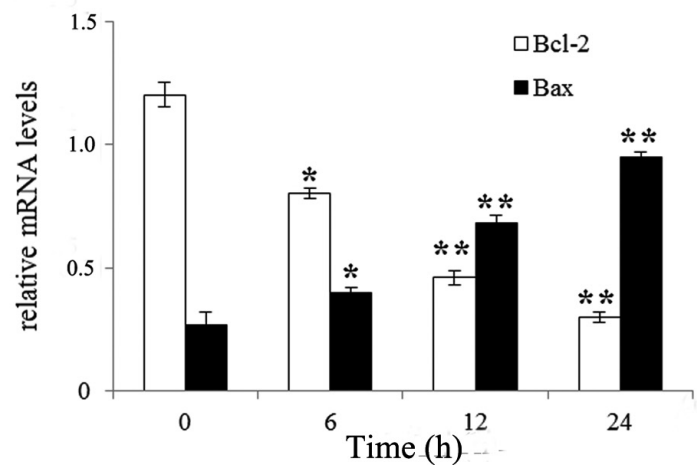

Figure 5. Expressions of cell cycle-related and cell apoptosis-related proteins in HT29 cells. A-B: expressions of cyclin D1, CDK4, Bcl-2, and Bax proteins in HT29 cell treated with $200 \mu \mathrm{g} / \mathrm{mL}$ of fengycin at different time points; C-D: after being treated with $200 \mu \mathrm{g} / \mathrm{mL}$ of fengycin, $\mathrm{qRT}$-PCR analysis showed the relative mRNA levels of cyclin D1, CDK4, Bcl-2, and Bax compared to the control (treated with fengycin at $0 \mathrm{~h}$ ) at different time points; E: expressions of cell apoptosis-related proteins in HT29 cells when cells were treated with $200 \mu \mathrm{g} / \mathrm{mL}$ of fengycin; F: when HT29 cells were treated with NAC, the release of $\mathrm{CytC}$ induced by fengycin from mitochondria was blocked. For western blot analysis, the relative mRNA expressions of the targets were normalized to $\beta$-actin. For RT-PCR analysis, expression levels of targets were calculated using the absolute standard curve method and then normalized to GAPDH. ${ }^{\star}$ stands for $\mathrm{P}<0.05$ and ${ }^{\star \star}$ stands for $\mathrm{P}<0.01$ compared with control group (cells treated with fengycin at 0 h).

Bacillus circulans DMS-2-derived fengycin shows cytotoxic activity against cancer cells [11]. Also, Duarte et al. proved that fengycin could inhibit breast cancer cell proliferation, which made fengycin to be a potential bio-surfactant for breast cancer treatment [12]. Ma et al. proved that anteiso-C17 fengycin $B$ could inhibit human leukemia-60 cell growth [22]. In agreement with previous studies, our results showed that HT29 cell proliferation was statistically inhibited by fengycin $(10 \mu \mathrm{g} / \mathrm{mL})$ at $72 \mathrm{~h}$ of incubation, and this inhibit effect was more apparent with high dose of fengycin (Figure 1), implying that fengycin may play some inhibit roles on colon cancer cell growth.

Meanwhile, our data displayed that fengycin could induce HT29 cell cycle arrest at G0/G1 stage (Figure 4). In previous reports, DNA damage can arrest cell cycle and activate cell apoptosis $[23,24]$. CDK4 is an important member of CDK family proteins that function in regulating cell cycle at G1 phase progression [25] while cyclin D1 is a cell cycle-related molecule at G1 phase and is associated with tumor susceptibility [26]. Cell cycle arrest in colon cancer was induced through down-regulation of cyclin D1/CDK4 complex [27]. Our results showed that fengycin application significantly decreased the protein and mRNA levels of CDK4 and cyclin D1, indicating that HT29 cells may be arrested in G1 phase by fengycin through cyclin-CDK4 mediated cell cycle.

Moreover, our results showed that high dose of fengycin statistically increased ROS level in HT29 cells, as well as on cell apoptosis compared to the controls (Figure 2 and 3). Studies have demonstrated that cell apoptosis was accompanied with lots of morphological changes such as DNA fragmentation, cell surface changes and nuclear condensation [28, 29]. ROS is a kind of normal metabolism or harmful xenobiotic exposure product [30], and various ROS induces cell damage or plays key roles in regulating cell apoptosis during its activation [31]. Roles of fengycin in colon cancer cell apoptosis 
have been not been fully reported. However, reduction of ROS protected gastrointestinal epithelium from radiationinduced damage [32]. Bufalin induces autophagy-mediated colon cancer cell apoptosis via ROS generation [33]. Also, high dose of fengycin could induced lung cancer 95D cell apoptosis through increasing ROS generation [9]. Based on our results, we speculated that high dose of fengycin may inhibit colon cancer progression by inducing cell apoptosis through ROS generation. On the other hand, $\mathrm{Bcl}-2$ and $\mathrm{Bax}$ are cell apoptosis-related proteins that performed verses expressions in cells [34]. Falling up of intracellular CytC is related to cell apoptosis activation [35]. In this study, fengycin decreased Bcl-2 but increased Bax protein and mRNA levels in HT29 cells with time increasing. Also, Caspase- 3 and Caspase- 6 are two Caspase family proteins that are related to cell apoptosis [36], and Caspase-3 has been considered as the apoptosis protein in the downstream cell apoptosis [37]. Interestingly, we found that expressions of cell apoptosis-related proteins in fengycin-treated HT29 cells could be suppressed by addition of NAC, a ROS inhibitor [19]. Richards et al. proved that accumulation of DNA damage in fibroblasts was caused by ROS generation but can be prevented by NAC [38]. Therefore, we speculated that fengycin could inhibit colon cell progression through inducing cell apoptosis through the Bcl-2/Bax pathway mediated by Caspase activity.

In conclusion, our study suggests that fengycin may play certain inhibit effects on the development and progression of colon cancer through involving in cell apoptosis process by targeting Bcl-2/Bax pathway. Fengycin may inhibit the development and progression of colon tumor through inhibiting cell proliferation, inducing cell apoptosis, increasing intracellular ROS generation, and inducing cell cycle arrest at G1 phase. Our study may provide theoretical basis for application of fengycin on colon treatment in clinical. However, comprehensive experimental studies are still needed to explore the molecular mechanism of fengycin on colon cancer in the near future.

\section{References}

[1] PHIPPS AI, LINDOR NM, JENKINS MA, BARON JA, WIN $\mathrm{AK}$, et al. Colon and rectal cancer survival by tumor location and microsatellite instability: the colon cancer family registry. Diseases of the colon \& rectum 2013; 56: 937-944. http:// dx.doi.org/10.1097/DCR.0b013e31828f9a57

[2] SIEGEL R, MA J, ZOU Z AND JEMAL A. Cancer statistics, 2014. CA: a cancer journal for clinicians 2014; 64: 9-29. http:// dx.doi.org/10.3322/caac. 21208

[3] DE GRAMONT A, VAN CUTSEM E, SCHMOLL H-J, TABERNERO J, CLARKE S, et al. Bevacizumab plus oxaliplatin-based chemotherapy as adjuvant treatment for colon cancer (AVANT): a phase 3 randomised controlled trial. The lancet oncology 2012; 13: 1225-1233. http://dx.doi. org/10.1016/S1470-2045(12)70509-0

[4] DRUSCO A, NUOVO GJ, ZANESI N, DI LEVA G, PICHIORRI F, et al. MicroRNA profiles discriminate among colon cancer metastasis. PloS one 2014; 9: e96670. http:// dx.doi.org/10.1371/journal.pone.0096670

[5] PINHEIRO DA SILVA F AND MACHADO MCC. Antimicrobial peptides: clinical relevance and therapeutic implications. Peptides 2012; 36: 308-314. http://dx.doi. org/10.1016/j.peptides.2012.05.014

[6] ZHANG Y, TENG D, MAO R, WANG X, XI D, et al. High expression of a plectasin-derived peptide NZ2114 in Pichia pastoris and its pharmacodynamics, postantibiotic and synergy against Staphylococcus aureus. Applied microbiology and biotechnology 2014; 98: 681-694. http://dx.doi.org/10.1007/ s00253-013-4881-2

[7] LUO C, LIU X, ZHOU H, WANG X AND CHEN Z. Nonribosomal Peptide Synthase Gene Clusters for Lipopeptide Biosynthesis in Bacillus subtilis 916 and Their Phenotypic Functions. Applied and environmental microbiology 2015; 81: 422-431. http://dx.doi.org/10.1128/AEM.02921-14

[8] CHENG C, LU Y, CHUANG K, HUNG W, SHIEA J, et al. Tumor-targeting prodrug-activating bacteria for cancer therapy. Cancer gene therapy 2008; 15: 393-401. http://dx.doi. org $/ 10.1038 /$ cgt.2008.10

[9] YIN H, GUO C, WANG Y, LIU D, LV Y, et al. Fengycin inhibits the growth of the human lung cancer cell line 95D through reactive oxygen species production and mitochondriadependent apoptosis. Anticancer Drugs 2013; 24: 587-598. http://dx.doi.org/10.1097/cad.0b013e3283611395

[10] ZHOU X, LU Z, LV F, ZHAO H, WANG Y, et al. Antagonistic action of Bacillus subtilis strain fmbj on the postharvest pathogen Rhizopus stolonifer. Journal of food science 2011; 76: M254M259. http://dx.doi.org/10.1111/j.1750-3841.2011.02160.x

[11] SIVAPATHASEKARAN C, DAS P, MUKHERJEE S, SARAVANAKUMAR J, MANDAL M, et al. Marine bacterium derived lipopeptides: characterization and cytotoxic activity against cancer cell lines. International Journal of Peptide Research and Therapeutics 2010; 16: 215-222. http://dx.doi. org/10.1007/s10989-010-9212-1

[12] DUARTE C, GUDI A EJ, LIMA CF AND RODRIGUES LR. Effects of biosurfactants on the viability and proliferation of human breast cancer cells. AMB Express 2014; 4: 40. http:// dx.doi.org/10.1186/s13568-014-0040-0

[13] WANG J, LIU J, WANG X, YAO J AND YU Z. Application of electrospray ionization mass spectrometry in rapid typing of fengycin homologues produced by Bacillus subtilis. Letters in applied microbiology 2004; 39: 98-102. http://dx.doi. org/10.1111/j.1472-765X.2004.01547.x

[14] VAN MEERLOO J, KASPERS GJ AND CLOOS J. Cell sensitivity assays: the MTT assay. In: editors. Cancer Cell Culture. Springer; 2011. p. 237-245.

[15] PATTINGRE S, TASSA A, QU X, GARUTI R, LIANG XH, et al. Bcl-2 antiapoptotic proteins inhibit Beclin 1-dependent autophagy. Cell 2005; 122: 927-939. http://dx.doi.org/10.1016/j. cell.2005.07.002

[16] AUBRY J-P, BLAECKE A, LECOANET-HENCHOZ S, JEANNIN P, HERBAULT N, et al. Annexin V used for measuring apoptosis in the early events of cellular cytotoxicity. Cytometry 1999; 37: 197-204. http://dx.doi.org/10.1002/(SICI)10970320(19991101)37:3<197::AID-CYTO6>3.0.CO;2-L 
[17] LI D, REN W, WANG X, WANG F, GAO Y, et al. A Modified Method using TRIzol ${ }^{\oplus}$ Reagent and Liquid Nitrogen Produces High-Quality RNA from Rat Pancreas. Applied biochemistry and biotechnology 2009; 158: 253-261. http://dx.doi. org/10.1007/s12010-008-8391-0

[18] RIO DC, ARES M, HANNON GJ AND NILSEN TW. Purification of RNA using TRIzol (TRI reagent). Cold Spring Harbor Protocols 2010; 2010: pdb. prot5439.

[19] MALIK F, KUMAR A, BHUSHAN S, KHAN S, BHATIA $A$, et al. Reactive oxygen species generation and mitochondrial dysfunction in the apoptotic cell death of human myeloid leukemia HL- 60 cells by a dietary compound withaferin A with concomitant protection by $\mathrm{N}$-acetyl cysteine. Apoptosis 2007; 12: 2115-2133. http://dx.doi.org/10.1007/s10495-007-0129-x

[20] BROGDEN KA. Antimicrobial peptides: pore formers or metabolic inhibitors in bacteria? Nature Reviews Microbiology 2005; 3: 238-250. http://dx.doi.org/10.1038/nrmicro1098

[21] ZASLOFF M. Antimicrobial peptides of multicellular organisms. Nature 2002; 415: 389-395. http://dx.doi. org/10.1038/415389a

[22] MA Z, WANG N, HU J AND WANG S. Isolation and characterization of a new iturinic lipopeptide, mojavensin A produced by a marine-derived bacterium Bacillus mojavensis B0621A. The Journal of antibiotics 2012; 65: 317-322. http://dx.doi.org/10.1038/ja.2012.19

[23] GARTNER A, MILSTEIN S, AHMED S, HODGKIN J AND HENGARTNER MO. A conserved checkpoint pathway mediates DNA damage-induced apoptosis and cell cycle arrest in C. elegans. Molecular cell 2000; 5: 435-443. http://dx.doi. org/10.1016/S1097-2765(00)80438-4

[24] TANG D, WU D, HIRAO A, LAHTIJM, LIU L, et al. ERK activation mediates cell cycle arrest and apoptosis after DNA damage independently of p53. Journal of Biological Chemistry 2002; 277: 12710-12717. http://dx.doi.org/10.1074/jbc.M111598200

[25] SHERR CJ AND ROBERTS JM. CDK inhibitors: positive and negative regulators of G1-phase progression. Genes Dev 1999; 13: 1501-1512. http://dx.doi.org/10.1101/gad.13.12.1501

[26] BALDIN V, LUKAS J, MARCOTE M, PAGANO M AND DRAETTA G. Cyclin D1 is a nuclear protein required for cell cycle progression in G1. Genes Dev 1993; 7: 812-821. http:// dx.doi.org/10.1101/gad.7.5.812

[27] WOLTER F, AKOGLU B, CLAUSNITZER A AND STEIN J. Downregulation of the cyclin D1/Cdk4 complex occurs during resveratrol-induced cell cycle arrest in colon cancer cell lines. The Journal of nutrition 2001; 131: 2197-2203.

[28] KIM G, KIM W, KIM K AND LEE J. DNA damage and mitochondria dysfunction in cell apoptosis induced by nonthermal air plasma. Applied Physics Letters 2010; 96: 021502. http:// dx.doi.org/10.1063/1.3292206
[29] LACHAUD C, DA SILVA D, COTELlE V, THULEAU P, XIONG TC, et al. Nuclear calcium controls the apoptotic-like cell death induced by d-erythro-sphinganine in tobacco cells. Cell calcium 2010; 47: 92-100. http://dx.doi.org/10.1016/j. ceca.2009.11.011

[30] CIRCU ML AND AW TY. Reactive oxygen species, cellular redox systems, and apoptosis. Free Radical Biology and Medicine 2010; 48: 749-762. http://dx.doi.org/10.1016/j. freeradbiomed.2009.12.022

[31] HAMANAKA RB AND CHANDEL NS. Mitochondrial reactive oxygen species regulate cellular signaling and dictate biological outcomes. Trends in biochemical sciences 2010; 35: 505-513. http://dx.doi.org/10.1016/j.tibs.2010.04.002

[32] COLON J, HSIEH N, FERGUSON A, KUPELIAN P, SEAL $S$, et al. Cerium oxide nanoparticles protect gastrointestinal epithelium from radiation-induced damage by reduction of reactive oxygen species and upregulation of superoxide dismutase 2. Nanomedicine: Nanotechnology, Biology and Medicine 2010; 6: 698-705. http://dx.doi.org/10.1016/j. nano.2010.01.010

[33] XIE C-M, CHAN WY, YU S, ZHAO J AND CHENG $\mathrm{CH}$. Bufalin induces autophagy-mediated cell death in human colon cancer cells through reactive oxygen species generation and JNK activation. Free Radical Biology and Medicine 2011; 51: 1365-1375. http://dx.doi.org/10.1016/j. freeradbiomed.2011.06.016

[34] DUO J, YING G-G, WANG G-W AND ZHANG L. Quercetin inhibits human breast cancer cell proliferation and induces apoptosis via Bcl-2 and Bax regulation. Mol Med Rep 2012; 5: 1453-1456.

[35] H TTEMANN M, PECINA P, RAINBOLT M, SANDERSON TH, KAGAN VE, et al. The multiple functions of cytochrome $\mathrm{c}$ and their regulation in life and death decisions of the mammalian cell: from respiration to apoptosis. Mitochondrion 2011; 11: 369-381. http://dx.doi.org/10.1016/j. mito.2011.01.010

[36] FAN T-J, HAN L-H, CONG R-S AND LIANG J. Caspase family proteases and apoptosis. Acta biochimica et biophysica Sinica 2005; 37: 719-727. http://dx.doi.org/10.1111/j.17457270.2005.00108.x

[37] BOATRIGHT KM AND SALVESEN GS. Mechanisms of caspase activation. Current opinion in cell biology 2003; 15: 725-731. http://dx.doi.org/10.1016/j.ceb.2003.10.009

[38] RICHARDS SA, MUTER J, RITCHIE P, LATTANZI G AND HUTCHISON CJ. The accumulation of un-repairable DNA damage in laminopathy progeria fibroblasts is caused by ROS generation and is prevented by treatment with $\mathrm{N}$-acetyl cysteine. Human molecular genetics 2011; 20: 3997-4004. http://dx.doi.org/10.1093/hmg/ddr327 